\title{
ESTABLISHMENT OF INFLAMMATORY MODEL OF BOVINE MAMMARY EPITHELIAL CELLS INDUCED BY LIPOTEICHOIC ACID
}

\author{
Ping Xu \\ Postgraduate student \\ Sumy National Agrarian University (Sumy, Ukraine) \\ College of Animal Science and Veterinary Medicine, Henan Institute of Science and Technology (Xinxiang, China) \\ ORCID: 0000-0002-3862-3567 \\ 121558423@1qq.com \\ Tetiana Fotina \\ Doctor of Veterinary Sciences, Professor \\ Sumy National Agrarian University (Sumy, Ukraine) \\ ORCID: 0000-0001-5079-2390 \\ tatiana.fotina@snau.edu.ua \\ Hanna Fotina \\ Doctor of Veterinary Sciences, Professor \\ Sumy National Agrarian University (Sumy, Ukraine) \\ ORCID: 0000-0002-0761-3681 \\ hanna.fotina@snau.edu.ua \\ Sanhu Wang \\ Professor \\ College of Animal Science and Veterinary Medicine, Henan Institute of Science and Technology (Xinxiang, China) \\ ORCID: 0000-0002-1300-3185 \\ wangsanhu2012@126.com
}

The mammary gland of the cow is particularly susceptible to infections of a wide range of pathogenic bacteria, including both Gram-positive and Gram-negative bacteria. The endotoxins of these pathogenic bacteria include peptidoglycan (PGN), lipoteichoic acid (LTA) and lipopolysaccharide (LPS), and they are the pathogen-associated molecular patterns (PAMPs) to induce mastitis. Cow mastitis is a detrimental factor in dairy farming industry. Lipoteichoic acid (LTA) is the main component of Staphylococcus aureus cell wall and the key cytotoxic factor causing inflammation. The aims of our work was to establish inflammatory model of study procedures were approved by the Animal Care and Use Committee of the Sumy National Agricultural University, Sumy, Ukraine, and the Henan Institute of Science and Technology, Xinxiang, China, and performed in accordance with the animal welfare and ethics guidelines.

The BMECs harvested from mid-lactation dairy cow milk were isolated by our laboratory. Briefly, the base medium for this cell is DMEM/F-12 (Gibco, USA, cat.12400-024). The complete growth medium included 10\% fetal bovine serum (Biological Industries, Israel, cat.04-011-1A/B), DMEM/F-12, and $10 \mathrm{ng} / \mathrm{mL}$ epidermal growth factor (Sigma, USA, cat. E4127). Cells were maintained at $37^{\circ} \mathrm{Cin}$ an incubator containing 5\% CO2. When cells grew to $80 \%$ confluency, the cells were rinsed twice with PBS, and then the primary mammary epithelial cells were trypsinized with $0.25 \%$ trypsin plus $0.02 \%$ EDTA and passaged. In this study, one inflammatory bovine mammary epithelial cell (BMEC) model was established by infecting the cells with LTA. The BMEC viability induced by LTA were evaluated. The expressions of pro-inflammatory cytokines (TNF- $\alpha$ and IL-6) were measured by ELISA and RT- $q P C R$. The results showed that the treatment of BMECs with LTA at $20 \mathrm{ng} / \mu \mathrm{L}$ for $24 \mathrm{~h}$ obviously improved TNF- $\alpha$ and IL-6 protein and gene expression levels. The establishment of the model will play an important role in the screening of anti-inflammatory drugs and the study of the mechanism of action in the future.

Key words: inflammatory, Lipoteichoic acid, Bovine, bovine mammary epithelial cells, cows mastitis.

DOI: https://doi.org/10.32845/bsnau.vet.2020.3.5

Introduction. Mastitis is one of the most prevalent and devastating inflammatory diseases in dairy cows over the world. It results in severe economic losses to the dairy industry, due to reduced milk yield and quality as well as increased treatment costs and the cull rate of cows. The annual total economic cost of mastitis was estimated at approximately 2 billion dollars and 1.55 billion euros in the USA and Europe, respectively (Zowalaty, A.E.E.al., 2018).

When a cow suffers from mastitis, its mammary epithelial cells can synthesize and secrete a large number of proinflammatory factors, mainly including interleukin (IL)-1ß, IL-6,

IL-8, tumor necrosis factor (TNF)- $\alpha$ and other cytokines. This might disturb the proliferation and milk synthesis of bovine mammary epithelial cells (BMECs), resulting in a decrease in milk yield and quality. The amounts and secretory activity of BMECs are related to milk yield (Sun, X.D.al., 2019), and the lipid content of milk, is an important indicator of milk quality (Shen, J. al., 2018). Triglyceride (TG) accounted for more than $98 \%$ of milk lipid, (Sheng, R. al., 2015). Fatty acids can be rapidly taken up and converted into lipid droplets by the lactating mammary gland (Viguier, C. al., 2009). Non-esterified fatty acid (NEFA) is a source of fatty acids and can increase milk fat synthesis (Szyda, 
J. al., 2019). A variety of genes, such as fatty acid synthase (FASN), acetyl coenzyme-A carboxylase 1 (ACACA), and stearoyl-CoA desaturase (SCD), etc., are involved in milk fat synthesis (Nagasawa, Y al., 2018). FASN catalyzes the synthesis of long-chain fatty acids (He, X.J al., 2019), ACACA is the ratelimiting enzyme catalyzing the first reaction step of fatty acid synthesis, and SCD is responsible for catalyzing the synthesis of mono-saturated fatty acids (Qi, L. al., 2014).

With the development of society and the expansion of dairy farming industry, bovine mastitis continues to be one of the most common diseases worldwide and has been seriously impacting on milk yield, milk composition and animal welfare (Seegers $\mathrm{H}$ et al., 2003). Mastitis is the persistent inflammatory response of mammary tissue attributed to intra-mammary invasion of pathogens (Rinaldi Met al., 2010). Bovine mammary gland inflammation is mainly caused by changes in metabolism, physiological trauma, and contagious or environmental pathogenic microorganisms (Oviedo-Boyso et al., 2007; Lahouassa $\mathrm{H}$ et al., 2007). So for mastitis, it is important to understand the mechanisms controlling the immune response at the molecular level (Wellnitz O and Bruckmaier RM,2012).

Literature Review. The BMECs was first infected when the pathogenic bacteria infect the mammary gland through the milk duct to reach the acinar of the mammary gland, and then inflammatory reactions occur (Park HJ et al., 2016). Bovine mammary epithelial cells (bMECs) are capable of initiating an innate immune response (IIR) to invading bacteria (Zhao and Lacasse, 2008).

Gram-positive bacteria as Staphylococcus aureus (S. aureus) is one of the major contagious pathogens which account for clinical and subclinical bovine mastitis through rapid multiplication and persistent adhesion in mammary gland tissue, and it a chronic and recurrent disease that affectdairy cattle worldwide (Bradley AJ.,2002).S. aureus by the mammary gland is not as well as known therecognition of Escherichia coli, another major pathogen for themammary gland. The counterpart of E. coli outer membrane lipopolysaccharide (LPS), asa proinflammatory bacterial agonist of the mammary glandinnate immune system, has not yet been established for S.aureus. Lipoteichoic acid (LTA) is the main component of $S$. aureus cell wall and the key cytotoxic factor causing inflammation(Schroder NW et al., 2003; Bougarn $S$ et al., 2010).LTA has beenshown to be an important pattern for immunerecognition of S. aureus (Van Amersfoort E.S. et al., 2003). One of the advantages of LTA as a tool tomodel inflammation, it is a definedbacterial PAMP which targets identifiedpattern recognition receptors (PRR) andincreasingly defined accessory molecules forrecognition and for the signaling cascade. LTA signals through toll like receptor 2(TLR2) in the bovine mammary gland by bMEpC (Schröder N.W.et al., 2003; Henneke P.et al., 2005). In this study, we used a purified commercial preparation of S. aureus LTA to determine whether the bovine mammary gland responds to LTA, to determine the dose-response effects, and to begin to characterize the induced inflammatory response. The establishment of the model will play an important role in the screening of anti-inflammatory drugs and the study of the mechanism of action in the future.

Aims. The aims of our work was to establish inflammatory model of bovine mammary epithelial cells induced by lipoteichoic acid

Materials and Methods. Bioethics statement The study procedures were approved by the Animal Care and Use Committee of the Sumy National Agricultural University, Sumy, Ukraine, and the Henan Institute of Science and Technology, Xinxiang, China, and performed in accordance with the animal welfare and ethics guidelines.

\section{Cultivation and treatment of BMECs}

The BMECs harvested from mid-lactation dairy cow milk were isolated by our laboratory. Briefly, the base medium for this cell is DMEM/F-12 (Gibco, USA, cat.12400-024). The complete growth medium included $10 \%$ fetal bovine serum (Biological Industries, Israel, cat.04-011-1A/B), DMEM/F-12, and $10 \mathrm{ng} / \mathrm{mL}$ epidermal growth factor (Sigma, USA, cat. E4127). Cells were maintained at $37^{\circ} \mathrm{Cin}$ an incubator containing $5 \% \mathrm{CO} 2$. When cells grew to $80 \%$ confluency, the cells were rinsed twice with PBS, and then the primary mammary epithelial cells were trypsinized with $0.25 \%$ trypsin plus $0.02 \%$ EDTA and passaged.

The BMECs were seeded into 6-well plated overnight at $37^{\circ} \mathrm{C}$. Then, the cells were treated with different concentration $(0$, 10, 20, 40, $80 \mathrm{ng} / \mathrm{\mu L}$ ) lipoteichoic acid (LTA) (Inviogen, Carlsbad, CA, USA, cat. trll-slta). After $12 \mathrm{~h}, 24 \mathrm{~h}$, and $48 \mathrm{~h}$ of stimulation, the BMECs were harvested for subsequent analyses.

Extraction and purification of total RNA

Total RNA was extracted from adherent BMECs using RNAiso Plus (TaKaRa, Dalian, P. R. China, cat. 9109) in accordance with the manufacturer's instructions. The assessment of the quantity and quality of RNA was verified using a NanoDrop 1000 (Thermo Scientific, Co., Ltd., P. R. China). The 260:280 nm optical density value was between 1.8 and 2.0. Then, the first-strand CDNA was synthesized using PrimeScriptTM RT reagent Kit with gDNA Eraser (TaKaRa, Dalian, P. R. China, cat. RR047A).

Cell Counting Kit-8 Assay

BMECs were seeded at a concentration of $1 \times 104$ cell per well in 96-well plates with eight replicates per condition. At the indicated timepoint, Cell counting KIT-8 (Beijing Solarbio Science \& Technology Co., Ltd., Beijing, P. R. China, cat.CK04)solution at a medium dilution of $1: 10$ diluted was added to each well and the plate was incubated at $37^{\circ} \mathrm{C}$ for $3 \mathrm{~h}$. The absorbance was measured at a wavelength of $450 \mathrm{~nm}$ by a micoplate reader (Bio-Rad, Hercules, CA), and the proliferation of each groups was calcuted using the equation: [(AS - Ab)/ (AC - Ab)] $100 \%$.

\section{CCK-8;}

AS: The absorbance value of the wells with cells, LTA,

AC: The absorbance value of the wells with cells, CCK-8; $\mathrm{Ab}$ : The absorbance value of the wells without cells.

Real-Time Cell Assay (RTCA)

The Real-Time Cell Assay (RTCA) was used to detect the effect of different concentrations $(0,10,20,40,80 \mathrm{ng} / \mu \mathrm{L})$ of $\mathrm{LTA}$ on $\mathrm{BMEC}$ proliferation. The $\mathrm{Cl}$ value is directly proportional to the number of cells. RTCA was determine the $\mathrm{Cl}$ value by measuring the impedance record.

Enzyme-linked immunosorbent assay (ELISA)

BMECs were cultured for $12 \mathrm{~h}, 24 \mathrm{~h}$, and $48 \mathrm{~h}$ in fresh serum-free medium after treatment with LTA. The medium was collected and centrifuged at 12,000 rpm for $5 \mathrm{~min}$ to remove cell debris. The levels of tumor necrosis factor a (TNF-a), and Interleukin-6 (IL-6) in the supernatants of BMECs were detected according to the ELISA kit instructions (Jiangsu Mei Biao Biological Technology Co., Ltd., Jiangsu, P. R. China, cat. MB- 
4838AIMB-4837A).

RT-qPCR analysis

Real-time PCR primers for amplification of mRNA were designed using Primer Premier 5.0 and synthesized by Sangon Biotech (Shanghai, P. R. China, Co., Ltd.). The primers used are in Table 1. Real-time quantitative PCR was performed using TB
Green Premix Ex TaqTM II (TaKaRa, Dalian, P. R. China, cat\#RR820B) on a 7500 Real-Time PCR system (Applied Biosystems Inc., Foster City, CA). GAPDH was used as a reference gene. The relative gene expression was calculated using the 2- $\triangle \triangle \mathrm{Ct}$ method.

Real-time quantitative PCR Primer Information

Table 1.

\begin{tabular}{|l|l|l|l|}
\hline Gene & Accession & Sequence & Product size (bp) \\
\hline TNF- $a$ & NM_173966.3 & $\begin{array}{l}\text { F:5'GGTGGTGGGACTCGTATGCCAATGC3' } \\
\text { R:5'GTGAGGAACAAGGGGGTGG3' }\end{array}$ & 151 \\
\hline IL-6 & NM_173923.2 & $\begin{array}{l}\text { F:5'ACAGCTATGAACTCCCGCTT3' } \\
\text { R:5' TCTCACATATCTCCTTTCTCATTGC3' }\end{array}$ & 226 \\
\hline GADPH & NM_001034034.2 & $\begin{array}{l}\text { F:5'AGATGGTGAAGGTCGGAGTG3' } \\
\text { R:5'CGTTCTCTGCCTTGACTGTG3' }\end{array}$ & 189 \\
\hline
\end{tabular}

Statistical analysis

The results are expressed as means \pm SD. Statistical differences were analyzed using a t-test for independent groups. The ANOVA was performed using GraphPad Prism version 6.01 (GraphPad Software Inc., San Diego, CA, USA). Statistical significance was declared as ${ }^{*} P<0.05$, ${ }^{* *} P<0.01$, and ${ }^{* *} P<$ 0.001 . Each experiment was repeated at least 3 times.

Results

CCK-8 and RTCA assay for cell viability
CCK-8 assay carried out to examine the viability of cells. The viability of BMECs infected with LTA were lower than that of the normal BMECs. RTAC was used to detect the effect of different concentrations of LTA on the proliferation of BMECs, the results were shown in Figure 2. With the increase of LTA concentration, the proliferation activity of BMEC cells was inhibited. According to the change of cell index value and different proliferation curves, the dynamic detection after LTA treatment of cells was found.

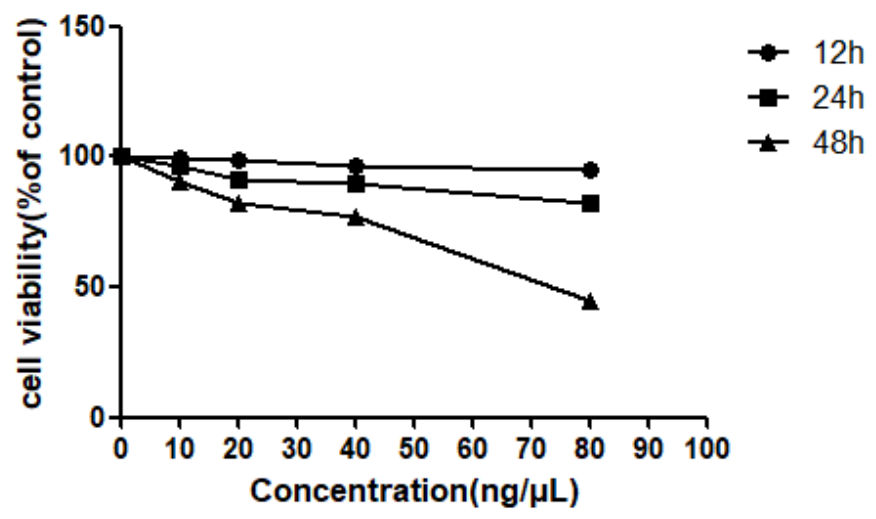

Fig. 1. The cell viability of LTA in BMEC

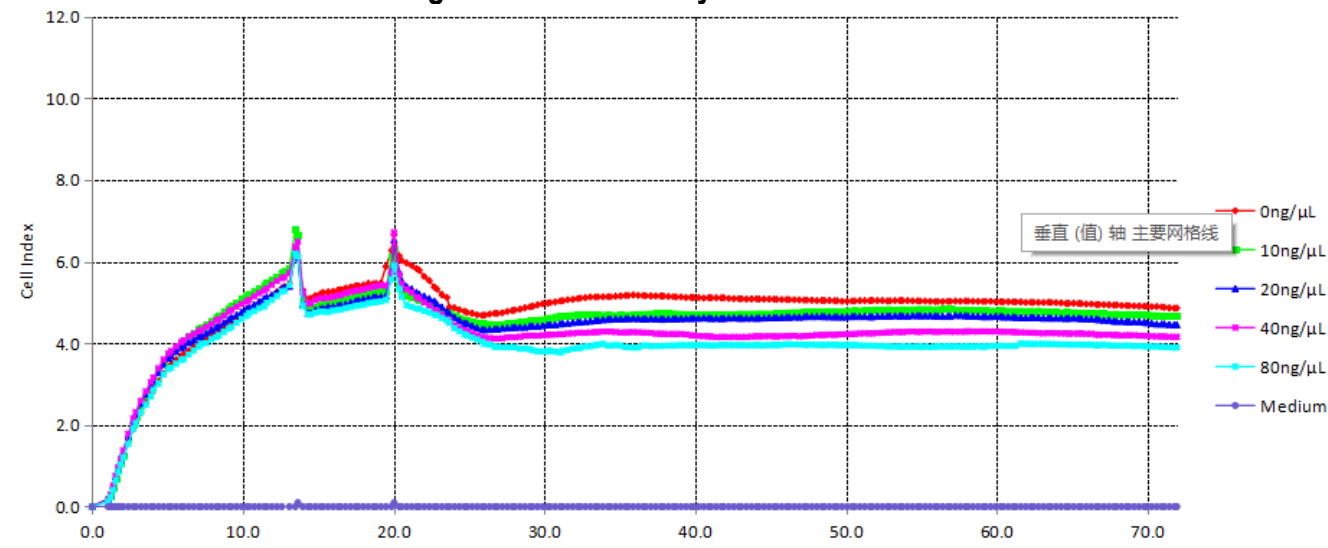

Fig. 2. Effect of LTA on the BMEC proliferation

Secretion of inflammatory cytokines by BMEC

It shown that the basal expression of TNF- $a$ and IL-6 protein in the culture supernatant of BMECs in the blank control group was low (Figure 3). BMECs were stimulated by different mass concentrations of LTA for different time, the expression of
TNF-a and IL-6 protein Significantly increased. When different mass concentrations of LTA acted on cells for $12 \mathrm{~h}, 24 \mathrm{~h}$, and $48 \mathrm{~h}$, the expression of TNF- $\alpha$ and IL- 6 protein reached its peak when the mass concentration of LTA was $20 \mathrm{ng} / \mathrm{\mu L}$. At the LTA mass concentration was 40 and $80 \mathrm{ng} / \mu \mathrm{L}$, the expression of TNF- $\alpha$ and 
IL-6 protein was lower than that at $20 \mathrm{ng} / \mathrm{\mu L}$, but they were still | significantly higher than the control group.
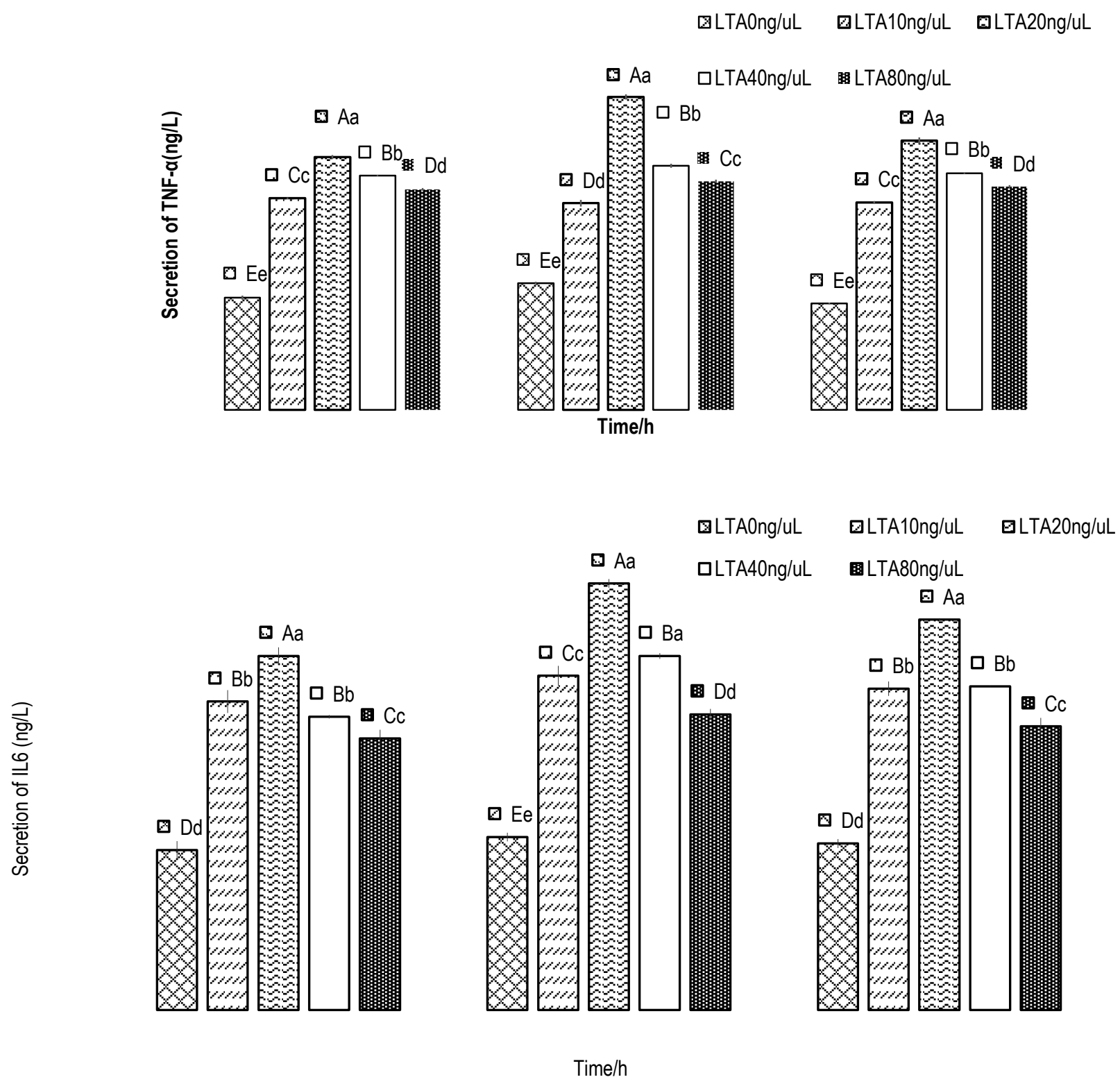

Fig. 3. Effect of LTA on the BMEC TNF- $\alpha$ and IL6 production. (A) (B)

Expression of inammatory cytokines by BMEC

It shown that the TNF- $\alpha$ and IL6 mRNA expression in the culture supernatant of BMECs in the blank control group was low (Figure 4). As the BMECs were stimulated by different mass concentrations of LTA for different time, the mRNA expression of TNF- $\alpha$ and IL- 6 increased significantly. The LTA acted on the cells for $12 \mathrm{~h}$ and $48 \mathrm{~h}$, the mRNA expression of IL-6 did not change significantly with the increase in mass concentration. However, the mRNA expression of TNF-a changes significantly. The mRNA expression of TNF- $a$ and IL6 reached the maximum, when the LTA concentration was $20 \mathrm{ng} / \mu \mathrm{L}$ with different times later. It can be seen that the LTA of 20 $\mathrm{ng} / \mu \mathrm{Ltreating}$ BMECs for $24 \mathrm{~h}$ can induce a significant cellular immune response in BMECs. 

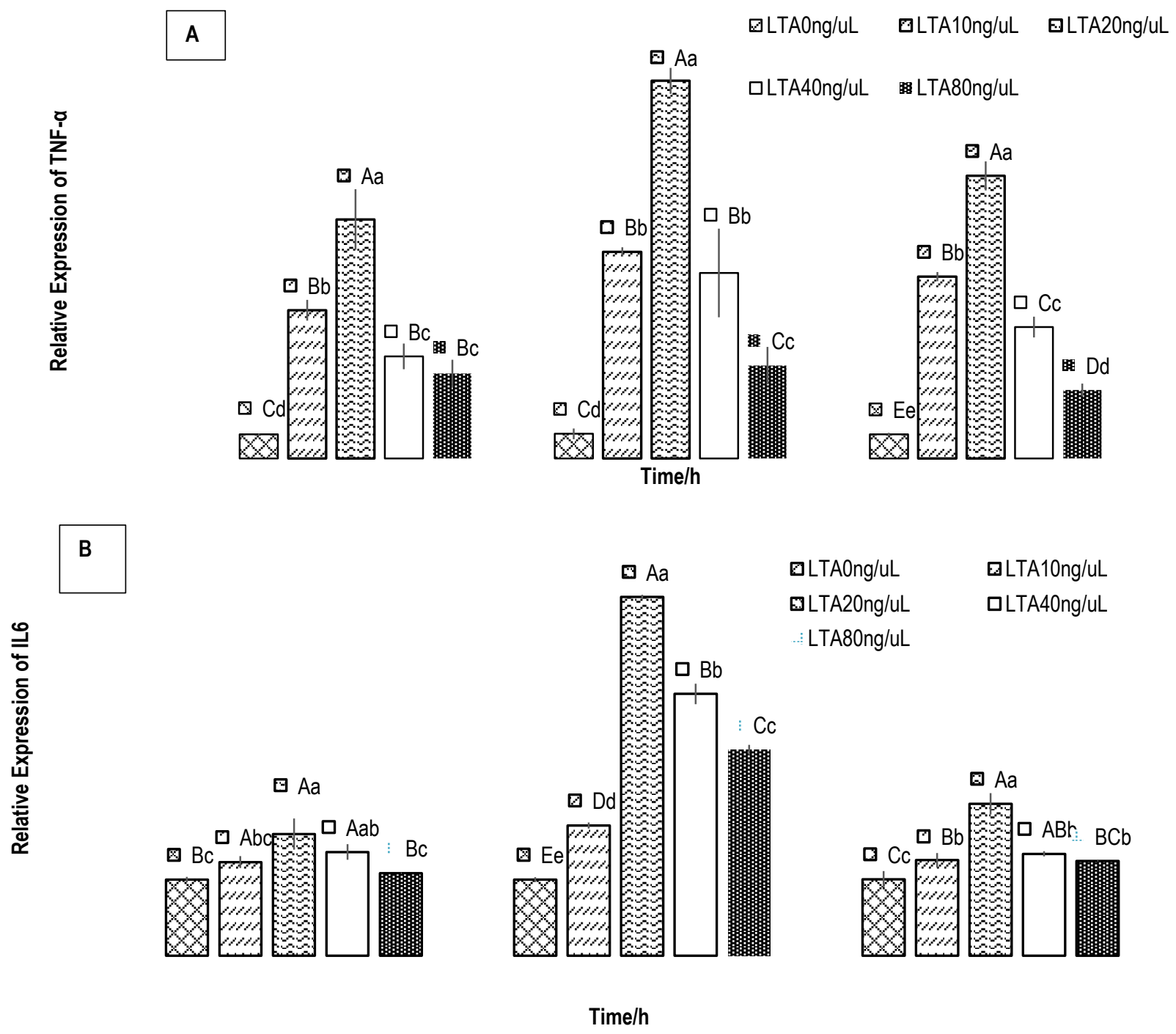

Fig. 4. Effect of LTA on the BMEC TNF- $\alpha$ and IL6 gene expression. A B

Discussion and Conclusion

Inflammatory response refers to the multi-cytokine involved in the occurrence and development of inflammation by regulating the balance between pro-inflammatory factors and anti-inflammatory systems (Wu T, et al., 2016; Dinarello, C. A. 2009). TNF- $a$ is the earliest and most important inflammatory mediator in the process of inflammation. IL 6 can induce B cells to differentiate and produce antibodies, and is a promoter of inflammatory response. LTA is an important component of the cell wall of Staphylococcus aureus and can activate inflammatory cells to cause inflammation. In the process of inflammation, LTA activates macrophages through the TLR2 receptor, which leads to the production of inflammatory cytokines TNF-a and IL6. The secretion of cytokines can induce further activation of inflammatory cells, leading to excessive or uncontrolled inflammatory response, and ultimately causing inflammatory case damage to host tissues and organs (Giovannin A E J, et al., 2017). Due to the immune characteristics of BMECs, specific inflammatory substances can be selected to induce BMECs to produce an immune response. The most used in the experiment is LPS and bacterial culture filtrate. However, there are few reports on the establishment of inflammation models by LTA on BMECs.In this study, LTA was used as a proinflammatory mediator. The two classic acute early cytokines, IL- 6 and TNF- $a$, were selected as the criteria for measuring the success of the model. CCK-8, RTAC, ELISA and qRT-PCR were used to test the method, the results showed that treatment of bovine mammary epithelial cells with $20 \mathrm{ng} / \mu \mathrm{L}$ LTA for $24 \mathrm{~h}$ can significantly increase the protein and gene expression levels of TNF- $\alpha$ and IL6. The establishment of this model could play an important role in screening anti-inflammatory drugs and studying the mechanism of action in the future.

\section{Author's contributions}

All authors participated in this article design. Ping $X u$ participated and performed writing and data collection. All authors read and approved the final manuscript. All authors contributed to the draft of the manuscript. All authors gave final approval for publication.

\section{Acknowledgments}

This research was financially supported by the National Natural Science Foundation of Henan (Grant No.182300410086) and Key Scientific Research Projects of Higher Education in Henan Province (No. 20A180025).

Conflict of interest. Author does not report any financial or personal connections with other persons or organizations, which might negatively affect the contents of this publication 
and/or claim authorship rights to this publication

\section{References.}

1.Bougarn S, Cunha P, Harmache A, Fromageau A, Gilbert F. B, \& Rainard P. (2010). Muramyl dipeptide synergizes with Staphylococcus aureus Lipoteichoic acid to recruit neutrophils in the mammary gland and to stimulate mammary epithelial cells. Clinical \& Vaccine Immunology, 17(11), 1797-1809. doi: 10.1128/CVI.00268-10.

2.Bradley AJ. (2002). Bovine mastitis: an evolving disease. Vet J, 164(2), 116-128. doi: 10.1053/tvjl.2002.0724.

3.Dinarello, C. A. (2009). Immunological and inflammatory functions of the interleukin-I family. Annu Rev Immunol., 27:519550. dio: 10.1146/annurev. immunol.021908.132612.

4.Giovannin A E J, Borne B H P, Wall S K, Wellntz O, Bruckmaier R M, \& Spadavecchia. (2017). Experimentally induced subclinical mastitis: Are lipopolysaccharide and lipoteichoic acid eliciting similar pain responses. Acta Veterinaria Scandi navica, 59(1), 40. dio: 10.1186/s13028-017-0306-z.

5.Henneke P., Morath S., Uematsu S., WeichertS., Pfitzenmaier M., Takeuchi O., Muller A., Poyart C., Akira S., Berner R., Teti G., Geyer A., Hartung T., \&GolenbockD.T., (2005). Role of lipoteichoic acid in the phagocyteresponse to group B streptococcus. J. Immunol, 174(10), 6449-6455.dio: 10.4049/jimmunol.174.10.6449.

6.Lahouassa H, Moussay E, Rainard P, \&Riollet C. (2007). Differential cytokine and chemokine responses of bovine mammary epithelial cells to Staphylococcus aureus and Escherichia coli. Cytokine, 38(1), 12-21. dio: 10.1016/j.cyto.2007.04.006.

7. Oviedo-Boyso J, Valdez-Alarcon JJ, Cajero-Juarez M, Ochoa-Zarzosa A, Lopez-MezaJE, Bravo-Patino A, \&BaizabalAguirre VM. (2007). Innate immune response of bovinemammary gland to pathogenic bacteria responsible for mastitis. Journal of Infection, 54(4), 399-409. dio: 10.1016/j.jinf.2006.06.010.

8. Park HJ, Lee WY, \& Jeong HY. (2016). Regeneration of bovine mammary gland in immunodeficient mice by transplantation of bovine mammary epithelial cells mixed with matrigel. International Journal of Stem Cells, 9(2), 186-191.

9. Rinaldi M, Li RW, \&Capuco AV. (2010). Mastitis associated transcriptomic disruptions in cattle. Veterinary Immunology and Immunopathology, 138(4), 267-279. dio: 10.1016/j.vetimm.2010.10.005.

10. Schroder NW, Morath S, Alexander C, Hamann L, Hartung T, Zahringer U, Gobel U B, Weber J R, \& Schumann R R. (2003). Lipoteichoic acid (LTA) of Streptococcus pneumoniae and Staphylococcus aureus activates immune cells via Toll-like receptor (TLR)-2, lipopolysaccharide-binding protein (LBP), and CD14, whereas TLR-4 and MD-2 are not involved. J Biol Chem, 278(18), 15587-15594. dio: 10.1074/jbc.M212829200.

11. Seegers H, Fourichon C, \&Beaudeau F.(2003). Production effects related to mastitis and mastitis economics in dairy cattle herds. Vet Res., 34(5), 475-491.Doi: 10.1051/vetres:2003027.

12. Van Amersfoort E.S., Van Berkel T.J., \&KuiperJ. (2003). Receptors, mediators, and mechanisms involvedin bacterial sepsis and septic shock, Clin. Microbiol.Rev, 16(3), 379-414. dio: 10.1128/CMR.16.3.379-414.2003.

13. Wellnitz O, \&Bruckmaier RM. (2012). The innate immune response of the bovine mammary gland to bacterial infection. Vet J., 192(2), 148-152. dio: 10.1016/j.tvjl.2011.09.013.

14. Wu T, Wang C, Ding L, Shen Y, Cui H, Wang M, \& Wang H.(2016). Arginine relieves the inflammatory response and enhances the casein expression in bovine mammary epithelial cells induced by lipopolysaccharide. Mediators Inflamm., 2016(4), 110.doi: $10.1155 / 2016 / 9618795$.

15. Zhao X, Lacasse P. (2008). Mammary tissue damage during bovine mastitis: causes andcontrol. Journal of Animal Science, 86(13), 57-65. doi: 10.2527/jas.2007-0302.

16. Chong, B.M.; Reigan, P.; Combs, K.D.M.; Orlicky, D.J.; McManaman, J.L. (2011). Determinants of adipophilin function in milk lipid formation and secretion. Trends Endocrinol. Metab. 22, 211-217.

17. Zowalaty, A.E.E.; Li, R.; Chen, W.; Ye, X. (2018). Seipin deficiency leads to increased endoplasmic reticulum stress and apoptosis in mammary gland alveolar epithelial cells during lactation. Biol. Reprod. 98, 570-578.

18. Sun, X.D.; Wang, Y.Z.; Loor, J.J.; Bucktrout, R.; Shu, X.; Jia, H.D.; Dong, J.H.; Zuo, R.K.; Liu, G.W.; Li, X.B.; et al. (2019). High expression of cell death-inducing DFFA-like effector a (CIDEA) promotes milk fat content in dairy cows with clinical ketosis. J. Dairy Sci. 2019, 102, 1682-1692.

19. Shen, J.; Zhu, B. (2018). Integrated analysis of the gene expression profile and DNA methylation profile of obese patients with type 2 diabetes. Mol. Med. Rep. 17, 7636-7644.

20. Sheng, R.; Yan, S.M.; Qi, L.Z.; Zhao, Y.L. (2015). Effect of the ratios of unsaturated fatty acids on the expressions of genes related to fat and protein in the bovine mammary epithelial cells. Vitr. Cell. Dev. Biol. Anim.51, 381-389.

21. Viguier, C.; Arora, S.; Gilmartin, N.; Welbeck, K.; O'Kennedy, R. (2009). Mastitis detection: Current trends and future perspectives. Trends Biotechnol. 27, 486-493.

22. Szyda, J.; Mielczarek, M.; Fraszczak, M.; Minozzi, G.; Williams, J.L.; Maksymiec, K.W. (2019). The genetic background of clinical mastitis in holstein-friesian cattle. Animal, 13, 2156-2163.

23. Nagasawa, Y.; Kiku, Y.; Sugawara, K.; Tanabe, F.; Hayashi, T. (2018). Exfoliation rate of mammary epithelial cells in milk on bovine mastitis caused by Staphylococcus aureus is associated with bacterial load. Anim. Sci. J. 89, 259-266.

24. He, X.J.; Lian, S.; Zhang, X.; Hao, D.D.; Shan, X.F.; Wang, D.; Sun, D.B.; Wu, R.; Wang, J.F. (2019). Contribution of PPAR gamma in modulation of LPS-induced reduction of milk lipid synthesis in bovine mammary epithelial cells. Int. J. Agric. Biol. 22, 835-839.

25. Qi, L.; Yan, S.; Sheng, R.; Zhao, Y.; Guo, X. (2014). Effects of saturated long-chain fatty acid on mRNA expression of 
genes associated with milk fat and protein biosynthesis in bovine mammary epithelial cells. Asian-Australas. J. Anim. Sci. 27, 414421.

Піне Сюй, аспірант, Сумський національний аграрний університет (м. Суми, Україна), Коледж наук про тварин та ветеринарну медицину, Інститут науки і технологій Хенань (Сіньсян, Китай) Україна)

Тетяна Фотіна, доктор ветеринарних наук, професор, Сумський національний аграрний університет (м. Суми, раїна)

Ганна Фотіна, доктор ветеринарних наук, професор, Сумський національний аграрний університет (м. Суми, Ук-

Санху Ван, професор Коледжу наук про тварин та ветеринарної медицини, Інститут науки і техніки Хенань, Сіньсян, Китай.

Встановлення моделі запалення епітеліальних клітин молочної залози корів

В роботі викладені результати дослідження встановлення моделі запалення епітеліальних клітин молочної залози корів що індукується ліпотейхоєвою кислотою. Мастит корів є фактором ризику для молочній галузі. До складу клітинної стінки Staphylococcus aureus входять муреїн і ліпотейхоєві кислоти. Ліпотейхоєва кислота (ЛТА) є головним компонентом клітинної стінки золотистого стафрілокока та ключовим цитотоксичним фрактором, що викликає запалення. Метою роботи було визначити модель запалення епітеліальних клітин молочної залози корів під дією ліпотейхової кислоти золотистого стасрілокока. Дослідження проводили в лабораторії безпеки та якості продуктів тваринництва Сумського НАУ, факультету ветеринарної медицини, Суми, Україна та на базі Науково-технічного інституту Хенань, Сіньсян, Китай. Дослідження були проведені згідно вимог Комітету з питань біоетики та виконувались відповідно до керівних принципів добробуту та етики тварин. Були відібрані зразки коров'ячого молока середнього періоду лактації, де лабораторно виділяли ЕКМЗ. Для дослідження використовували метод імуноферментного аналізу та ПЛР діагностику. Проводили аналіз клітин з використанням ПЛР у реальному часі (RTCA) для виявлення впливу різних концентрацій (0, 10, 20, 40, 80 нг / мкл) ліпотейхової кислоти (LTA) на проліферацію EKMЗ. Результати IФA та qRT-PCR показали, що обробка епітеліальних клітин молочної залози великої рогатої худоби 20 нг / мкл LTA протягом 24 годин може значно підвищити рівень експресії білка та генів TNF-a ma IL-6. Створення цієї моделі може зіграти важливу роль у скринінгу протизапальних препаратів та вивченні механізму дії в майбутньому.

Ключові слова: ліпотейхова кислота, мастит корів, золотистий стафрілокок. епітеліальні клітини молочної залози.

Дата надходження до редакції: 27.10.2020 р. 